\title{
Diets of Bison and Cattle on a Seeded Range in Southern Utah
}

\author{
DIRK VAN VUREN AND MARTIN P. BRAY
}

\begin{abstract}
Diets of bison (Bison bison) and cattle (Bos taurus) were evaluated on a southern Utah range seeded to crested wheatgrass ( $\mathrm{Agro}$ pyron desertorum) and alfalfa (Medicago sativa). Bison feces comprised $96 \%$ grasses and sedges, $4 \%$ forbs, and $1 \%$ shrubs. Cattle feces comprised $88 \%$ grasses and sedges, $4 \%$ forbs, and $8 \%$ shrubs. Diets were $91 \%$ similar, indicating a high potential for competition between bison and cattle.
\end{abstract}

The Henry Mountains of southern Utah have been used as summer range by cattle (Bos taurus) since the late 1800's. In 1941, 18 bison (Bison bison) were introduced, and the population was about 250 in 1980 . Summer distribution of bison and cattle overlap substantially, resulting in competition for forage (Nelson 1965). To increase carrying capacity for bison and cattle, several thousand hectares of pinyon pine (Pinus edulis) and juniper (Juniperus spp.) woodland were cleared in the late 1960's and seeded to crested wheatgrass (Agropyron desertorum) and alfalfa (Medicago sativa). Seeded a reas currently account for a major portion of forage consumed by bison and cattle. Proper allocation of forage on seeded areas requires information on the diets of bison and cattle. Studies comparing bison and cattle diets are limited to shortgrass prairie (Peden et al. 1974) and shrub-steppe plant communities (Van Vuren 1979). Our objective was to evaluate diet composition and diet overlap of bison and cattle on a seeded area in the Henry Mountains.

\section{Study Area and Methods}

The study area was about 200 ha in size and was located at 2,350 $m$ elevation on the northwest slope of Mount Pennell, Garfield County, Utah. Precipitation averaged $32 \mathrm{~cm}$ per year, and native vegetation was pinyon-juniper woodland. Vegetation on the study area, which was cleared of all trees in 1968, was a mixture of seeded forages and re-established native species. Common grasses and sedges were crested wheatgrass, squirreltail (Sitanion hystrix), Indian ricegrass (Oryzopsis hymenoides), and sedges (Carex spp.). Common forbs were alfalfa and groundsel (Senecio spp.). Pinyon pine and juniper seedlings were common. Shrubs included bitterbrush (Purshia tridentata), rabbitbrush (Chrysothamnus spp.), sagebrush (Artemisia spp.), snakeweed (Gutierrezia sarothrae), and Gambel oak (Quercus gambelii).

Diets of bison and cattle were estimated by fecal analysis. One 15-cc sample was collected from each of 34 fresh cattle feces and 35 fresh bison feces on 10 September 1980 . Feces were deposited by 24 bison and 15-20 cattle that had grazed exclusively on the study site for the preceding four days. Fecal samples were analyzed microhistologically. Five microscope slides were prepared from each sample, and plant fragments were identified in 20 microscope fields per slide. Frequency of occurrence of each species was calculated and converted to relative density, which is an approximation of dry

Authors are graduate student, Department of Systematics and Ecology, University of Kansas, Lawrence 66045, and wildlife biologist, DEH Wildlife Branch, Fort Bragg. N.C. 28307 .

This study was funded by a grant-in-aid from the National Rifle Association. We thank B.E. Coblentz, J.A. Crawford, and A.H. Winward for helpful criticism of the manuscript. Fecal analysis was done by Composition Analysis Laboratory, Colorado State University.

Manuscript received March 26, 1982. weight for each species (Sparks and Malechek 1968).

Availability of herbaceous vegetation was estimated by clipping plants in 30 quadrats $(0.75$ by $1.50 \mathrm{~m})$ located randomly throughout the study area. Shrubs were not clipped. Plants were separated by species, air dried for 14 days, and weighed.

Differences in amounts of forages identified in bison and cattle feces were evaluated with a $t$-test. Diet overlap was evaluated with Kulcyznski's similarity index (Oosting 1956).

\section{Results and Discussion}

Feces of bison and cattle contained primarily grasses and sedges (Table 1). Cattle feces, however, had less grass $(P<0.05)$ and more shrubs $(P<0.05)$ than did bison feces. Oak was common in cattle feces, but was insignificant in bison feces. Our results are consistent with other comparisons of bison and cattle diets. Peden et al. (1974) and Van Vuren (1979) reported that both species consumed mostly grasses, although cattle diets were more variable and included more forbs or shrubs than did bison diets.

Fecal content of both species was related generally to forage availability. Wheatgrass totalled $80 \%$ of available herbaceous vegetation, and comprised $86 \%$ of bison feces and $81 \%$ of cattle feces. Alfalfa, the most common forb in the study area, was also the most important forb in feces of both bison and cattle. Fecal percentages of alfalfa, however, seemed low when compared with availability. The cause may have been differential digestibility of forages, resulting in underrepresentation of forbs in feces (Vavra et al. 1978). Also, the study was conducted in late summer, when alfalfa

Table 1. Herbage availability and composition of bison and cattle feces on a seeded area in the Henry Mountains, Utah.

\begin{tabular}{|c|c|c|c|}
\hline \multirow[b]{2}{*}{ Forage } & \multirow{2}{*}{$\begin{array}{c}\text { Availability } \\
(\mathrm{kg} / \mathrm{ha})\end{array}$} & \multicolumn{2}{|c|}{$\%$ relative density of feces } \\
\hline & & Bison & Cattle \\
\hline \multicolumn{4}{|l|}{ Grasses and sedges } \\
\hline Agropyron spp. & 489 & 86 & 81 \\
\hline Bromus spp. & 2 & $T^{1}$ & $\mathbf{T}$ \\
\hline Carex spp. & 2 & $\mathbf{T}$ & $\mathrm{T}$ \\
\hline Oryzopsis hymenoides & 13 & 1 & 1 \\
\hline Poa spp. & 0 & 2 & 2 \\
\hline Sitanion hystrix ${ }^{2}$ & 34 & 6 & 3 \\
\hline Total ${ }^{2}$ & 540 & 96 & 88 \\
\hline \multicolumn{4}{|l|}{ Forbs } \\
\hline Lesquerella spp. & 0 & $\mathbf{I}$ & 1 \\
\hline Medicago sativa & 55 & 3 & 4 \\
\hline Senecio spp. & 11 & $\mathbf{T}$ & 0 \\
\hline Total & 72 & 4 & 4 \\
\hline \multicolumn{4}{|l|}{ Shrubs $^{3}$} \\
\hline Artemisia spp. & & 0 & 1 \\
\hline Quercus gambelii² & & $\mathbf{T}$ & 5 \\
\hline Shepherdia rotundifolia & & $\mathbf{T}$ & i \\
\hline Symphoricarpos spp. & & $\mathbf{T}$ & $T$ \\
\hline Total ${ }^{2}$ & & 1 & 8 \\
\hline
\end{tabular}

Trace $(<0.5 \%)$.

${ }^{2}$ Occurred in different percentages $(P<0.05)$ in bison and cattle feces.

${ }^{3}$ Availability of shrubs was not determined. 
plants had been grazed close to the ground; the remaining plant parts, mostly large stems with few leaves, probably were of relatively low palatability. Groundsel, a common forb, was insignificant in feces of both bison and cattle; plants in the genus Senecio often are unpalatable or poisonous to livestock (USDA Forest Service 1937).

We calculated a similarity index of $91 \%$, indicating a high degree of overlap between diets of bison and cattle. Competition between bison and cattle will result on seeded areas in the Henry Mountains in late summer unless adequate forage is allocated to both species on the basis of diet similarity and forage availability.

\section{Literature Cited}

Nelson, K.L. 1965. Status and habits of the American buffalo (Bison bison) in the Henry Mountain area of Utah. Utah Dep. Fish and Game Pub. No. 65-2.
Oosting, H.J. 1956. The study of plant communities. W.H. Freeman and Co., San Francisco.

Peden, D.G., G.M. Van Dyne, R.W. Rice, and R.M. Hansen. 1974. The trophic ecology of Bison bison L. on shortgrass plains. J. Appl. Ecol. 11:489-497.

Sparks, D.R., and J.C. Malechek. 1968. Estimating percentage dry weight in diets using a microscope technique. J. Range Manage. 21:264-265.

USDA Forest Service. 1937. Range plant handbook. U.S. Government Printing Office, Washington, D.C.

Van Vuren, D. 1979. Ecology and behavior of bison in the Henry Mountains, Utah. MS thesis, Oregon State Univ., Corvallis.

Vavra, M., R.W. Rice, and R.M. Hansen. 1978. A comparison of esophageal fistula and fecal material to determine steer diets. J. Range Manage. 31:11-13. 